\title{
ANALISIS PENGARUH PERKEMBANGAN PENDAPATAN PERUSAHAAN, TOTAL ASET, DAN TOTAL TINGKAT UPAH TERHADAP JUMLAH TENAGA KERJA PERUSAHAAN
}

\author{
Analysis Development Impact of the Company's Income, Total Assets, \\ and Total Wage Level Against the Amount of labour \\ Anas Tain ${ }^{1)}$; Ary Bakhtiar2); Ratu Cahyaningrum Wulandari ${ }^{3)}$ \\ 1),2),3) Program Studi Agribisnis, Fakultas Pertanian Peternakan, Universitas \\ Muhammadiyah Malang \\ Email: ratucandari@gmail.com
}

\begin{abstract}
The research has a purpose as follows, analyzing the impact between the total income of agricultural sector companies with total national income. Analyzing the impact of total income, total assets, and total wage level to the labour of agricultural sector companies. Analyzing the frequently relation between the amount of labour in agricultural sector companies with total national income. National income with company income does not have a relation but, there is a significant impact. The results of the analysis of the impact of developments on the amount of labor in agricultural sub-sector companies are the total asset variables that have a significant impact. while company income and total wage level variables do not significantly influence the number of workers. The results of the analysis of the influence of the development of state revenue and the number of labour back and forth have a significant effect. Whereas the company income variables and total wage level not significantly influence the amount of labour. The results of the analysis development national income and the amount of labour frequently have a significant impact.
\end{abstract}

Keywords: Company Income, Total Assets, Total Wage Level, Amount Of Labour, and National Income.

\section{ABSTRAK}

Perusahaan memiliki peran penting dalam mengurangi dan menambah angka pengangguran karena perusahaan menjadi sarana dalam penyerapan tenaga kerja. Penelitian memiliki tujuan yaitu untuk menganalisis pengaruh pendapatan perusahaan 
sektor pertanian dengan pendapatan negara, Menganalisis pengaruh pendapatan, total aset, dan total tingkat upah terhadap jumlah tenaga kerja perusahaan sektor pertanian. Menganalisis hubungan bolak balik antara jumlah tenaga kerja pada perusahaan sektor pertanian dengan pendapatan negara. Pendapatan negara dengan pendapatan perusahaan tidak memiliki hubungan tetapi, terdapat pengaruh yang signifikan. Hasil dari analisis pengaruh perkembangan terhadap total tenaga kerja perusahaan sub sektor pertanian adalah variabel total aset yang berpengaruh secara signifikan, sedangkan variabel pendapatan perusahaan dan total tingkat upah tidak berpengaruh secara signifikan terhadap jumlah tenaga kerja. Hasil analisis pengaruh perkembangan pendapatan negara dan jumlah tenaga kerja secara bolak balik memiliki pengaruh yang signifikan.

Kata Kunci : Jumlah Tenaga Kerja, Pendapatan Negara, Pendapatan Perusahaan, Total Aset, dan Total Tingkat Upah

\section{PENDAHULUAN}

Tingkat pengangguran data per Juni tahun 2019, Indonesia menempati urutan ke-2 tertinggi pada negara ASEAN. Tingkat pengangguran Indonesia sebesar $5,01 \%$. Isu tentang tenaga kerja beberapa tahun terakhir, tenaga kerja asing yang masuk ke Indonesia, serta keadaan perekonomian Indonesia yang tidak stabil. Berdasarkan pemerintahan pusat dan daerah UMP Indonesia tertinggi ke-3 dikawasan ASEAN. UMP yang tinggi menjadi salah satu pertimbangan investor. Efek dari kemajuan teknologi dimana perusahaan ingin memaksimalkan laba dengan menekan biaya produksi salah satunya pada biaya tenaga kerja. Kemajuan teknologi membuat tergantikannya tenaga kerja manusia oleh tenaga mesin. Penyebab pengangguran dalam suatu masyarakat, dikarenakan pemanfaatan salah satu modal dasar yang kurang efisien dan pembatasan pilihan yang tersedia. Angka pengangguran jika nantinya mulai mendekati tingkat yang cukup tinggi, maka hal itu dapat mengganggu stabilitas ekonomi masyarakat suatu negara (Hasibuan, 2014). Perusahaan yang menggunakan modal dengan tidak efisien dapat menambah pengangguran dengan adanya PHK, perusahaan yang bangkrut sehingga tidak beroperasi dan tidak membutuhkan tenaga kerja. Perusahaan memiliki peran penting dalam mengurangi dan menambah angka pengangguran karena perusahaan menjadi sarana dalam penyerapan tenaga kerja. Berdasarkan paparan uraian diatas peneliti memiliki tujuan penelitian yaitu menganalisis pengaruh pendapatan perusahaan sektor pertanian dengan pendapatan negara, Menganalisis pengaruh pendapatan, total aset, dan total tingkat upah terhadap jumlah tenaga kerja perusahaan sektor pertanian. Menganalisis hubungan bolak balik antara jumlah tenaga kerja pada perusahaan sektor pertanian dengan pendapatan negara.

376 | Anas Tain, Ary Bakhtiar; Analisis Pengaruh Perkembangan... 


\section{METODE PENELITIAN}

Metode analisis data yang digunakan dalam penelitian ini yaitu analisis deskriptif kualitatif dan kuantitatif. Penelitian ini menggunakan data sekunder dengan jenis runtun waktu (time series) selama kurun waktu 2009-2018 (10 tahun) pada 9 perusahaan pertanian, yaitu PT. Astra Agro Lestari Tbk, PT. Bakrie Sumatera Plantations Tbk, PT. Gozco Plantations Tbk, PT. PP London Sumatra Indonesia Tbk, PT. Sampoerna Agro Tbk, PT. Sinar Mas Agro Tbk, PT. Bisi International Tbk, PT. Tunas Baru Lampung Tbk, dan PT. Dharma Samudera Fishing Indonesia Tbk. Data yang digunakan bersumber dari website Bursa Efek Indonesia dalam laporan tahunan (Annual report) serta sumber penelitian lainnya berasal dari buku, jurnal, Badan Pusat Statistik (BPS), internet, pustaka, dan literatur-literatur lainnya yang mendukung pelaksanaan penelitian ini.

Teknik pengambilan sampel penelitian menggunakan metode purposive sampling pada perusahaan dibidang pertanian dimana pemilihan sampel dilakukan dengan klasifikasi perusahaan sudah terdaftar pada Bursa Efek Indonesia dibawah tahun 2009, menerbitkan laporan keuangan yang sudah diaudit, dan perusahaan mendapatkan laba atau rugi dalam kurun waktu 20092018, sehingga didapat tujuh perusahaan yang menjadi sampel dalam penelitian. Waktu yang digunakan peneliti untuk penelitian ini dilaksanakan bulan November-Desember 2019. Penelitian ini dilakukan pada website Bursa Efek Indonesia (www.idx.co.id) dengan mengambil data pada perusahaan yang tergabung pada BEI.

\section{Metode Analisa Data}

\section{Uji Analisis Jalur (Path Analysis)}

Metode analisis dalam penelitian ini menggunakan analisis jalur (Path analysis). Analisis jalur adalah sebagai perluasan dari analisis regresi linear berganda. Analisis jalur adalah analisis regresi yang digunakan untuk menaksir hubungan kausalitas antar variabel (Model casual) yang sudah ditetapkan sebelumnya berdasarkan teori yang sudah ada. Hubungan kausalitas antar variabel ini sudah dibentuk dengan menggunakan model berdasarkan landasan teoritis (Ghozali, 2013). Perhitungan jalur menjelaskan hubungan pendapatan perusahaan (X1), total aset (X2), dan total tingkat upah (X3) baik secara langsung ataupun secara tidak langsung terhadap total tenaga kerja perusahaan $(\mathrm{Y})$. variabel eksogen lainnya yaitu total pendapatan negara $(Z)$ diduga memiliki pengaruh dengan total pendapatan perusahaan. Variabel iraversible terdapat pada penelitian dimana kedudukannya dapat dibolak balik yaitu variabel jumlah tenaga kerja $(Y)$ dengan variabel pendapatan negara $(Z)$. Model analisis jalur dalam penelitian, sebagai berikut : 


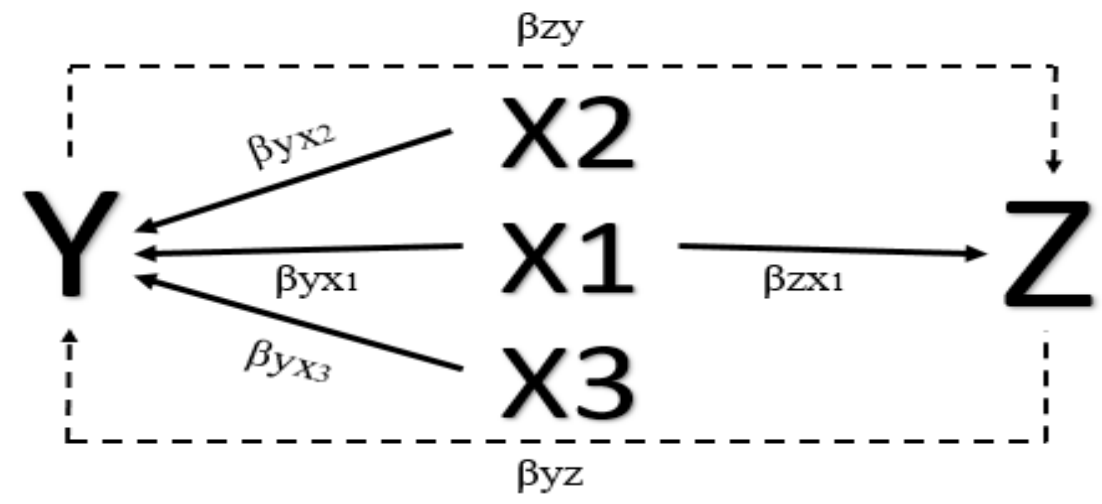

Gambar 1.

Metode Analisis Jalur

Keterangan:

Byx1 : koefisien jalur berpengaruh langsung pada pendapatan perusahaan terhadap jumlah tenaga kerja

Byx2 : koefisien jalur berpengaruh langsung pada total aset terhadap jumlah tenaga kerja perusahaan

Byx3 : koefisien jalur berpengaruh langsung pada total tingkat upah terhadap jumlah tenaga kerja perusahaan

$\beta z x 1$ : koefisien jalur berpengaruh langsung pada pendapatan perusahaan terhadap pendapatan Negara

$\beta z y$ : koefisien jalur berpengaruh langsung pada pendapatan negara terhadap jumlah tenaga kerja perusahaan

$\beta y z$ : koefisien jalur berpengaruh langsung pada jumlah tenaga kerja perusahaan terhadap pendapatan negara

Model analisis jalur yang digunakan dalam penelitian ini dapat diuraikan dalam persamaan struktural berikut:

$$
\begin{aligned}
& Y=\beta y \times 1 X 1+\beta y x 2 X 2+\beta y \times 3 X 3+\beta y z Z+\varepsilon 1 \ldots \ldots \ldots \ldots \ldots . . .1 \\
& \mathrm{Z}=\beta \mathrm{zx} 1 \mathrm{X} 1+\beta \mathrm{zy} Y+\varepsilon 2 \ldots \ldots \ldots \ldots \ldots \ldots \ldots \ldots \ldots \ldots \ldots \ldots \ldots \ldots \ldots \ldots . . .2
\end{aligned}
$$

dimana:

X1 : Pendapatan Perusahaan

X2 : Total Aset

X3 : Total Tingkat Upah

Y : Jumlah Tenaga Kerja

Z : Pendapatan Negara

¿1.2 : Variabel pengganggu 


\section{HASIL DAN PEMBAHASAN}

\section{Pengaruh Pendapatan Perusahaan dengan Pendapatan Negara}

Tolak ukur perekonomian suatu negara salah satunya yaitu total pendapatan negara dan produk nasional. Pendapatan perusahaan berkaitan dengan produk nasional sehingga total pendapatan perusahaan memiliki hubungan dengan total pendapatan negara. Negara yang melakukan perdagangan internasional memiliki banyak faktor pendorongnya, yaitu untuk memenuhi kebutuhan permintaan akan barang dan jasa dalam negeri, serta agar memperoleh keuntungan dan dapat meningkatkan pendapatan negara (Nasution \& Faisal, 2016). Perdagangan internasional yang dimaksudkan yaitu proses impor dan ekspor antar negara, dimana perusahaan berperan penting dalam proses perdagangan internasional. Transaksi yang terjadi antar negara ini dapat mempengaruhi pendapatan negara dan juga pendapatan perusahaan. Hal ini dapat dilihat dari data pendapatan perusahaan pertanian dan pendapatan negara disajikan pada diagram untuk melihat hubungan antar variabel, sebagai berikut:

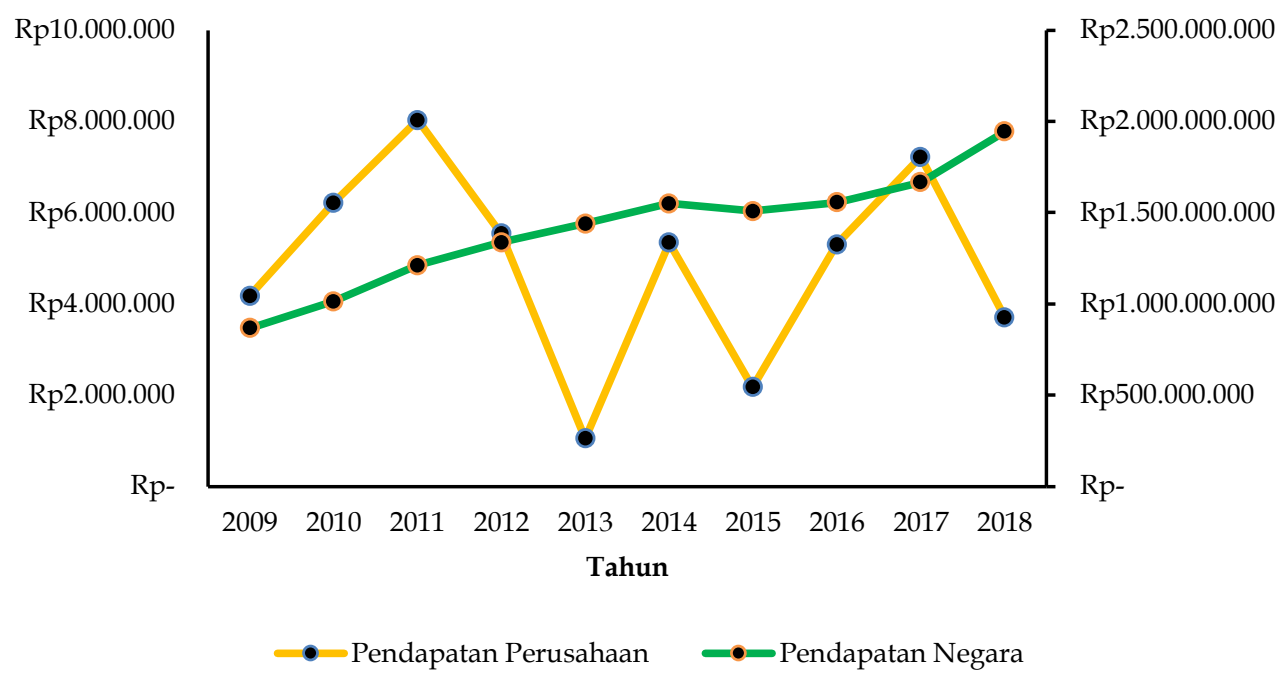

Gambar 2.

Total Pendapatan Negara dan Perusahaan

Berdasarkan gambar 2. pada tahun 2009-2014 total pendapatan negara mengalami peningkatan setiap tahunnya, karena jumlah penerimaan dari pajak yang rata-ratameningkat sebesar $13,21 \%$ data didapat dari BPS dan penerimaan dari bukan pajak juga jumlahnya meningkat setiap tahunnya. Total pendapatan perusahaan mengalami peningkatan pada tahun 2009-2011, tetapi total pendapatan perusahaan mengalami penurunan pada tahun 2012 dan 2013. Hal 
ini dipengaruhi oleh sampel penelitian yang sebagian besar (7 perusahaan) merupakan perusahaan dibidang perkebunan sawit. Harga CPO dunia dari sumber World Bank Comodity Price Date harga CPO pada tahun 2009-2011 sebesar $\$ 725,3 / \mathrm{mt}-\$ 1.123 / \mathrm{mt}$ yang mengalami peningkatan tiap tahunnya. Harga CPO pada tahun 2012 sebesar $\$ 1.110 / \mathrm{mt}$ dan tahun $2013 \$ 940,5 / \mathrm{mt}$, harga CPO mengalami penurunan dibandingkan tahun sebelumnya. Tahun 2014 terjadi peningkatan pada pendapatan perusahaan, karena harga $\mathrm{CPO}$ meningkat sebesar \$1.279/mt.

Memaksimalkan pendapatan perusahaan dengan pertimbangan dari harga jual produk yang dihasilkan oleh suatu perusahaan. Harga jual harus meliputi biaya-biaya yang dikeluarkan dalam proses produksi. Penetapan harga jual ini bertujuan untuk menutupi biaya-biaya yang dipergunakan dalam proses produksi (Maruta, 2018). Harga jual yang mengalami peningkatan atau penurunan akan mempengaruhi pendapatan perusahaan. Harga $\mathrm{CPO}$ dunia yang tinggi akan meningkatkan harga jual CPO dan membuat penadapatan perusahaan meningkat, dan sebaliknya.

Tahun 2015 total pendapatan negara mengalami penurunan dan total pendapatan perusahaan mengalami penurunan. Hal ini terjadi karena pertumbuhan ekonomi Indonesia pada tahun 2015 tumbuh dibawah 5\%. Ekspor yang rendah menjadi penyebab pertumbuhan ekonomi yang tidak sesuai dengan asumsi pemerintah, serta turunnya harga komoditas, dan isu dari Bank Sentral AS (The Federal Reserve/The Fed) yang berencana akan menaikkan suku bunga, namun The Fed bersikap tidak pasti sementara pasar sudah mulai mengantisipasi kenaikan suku bunga yang menyebabkan ekspor mengalami penekanan dikutip dari CNBC Indonesia. Menurut Retnasih, Agustin, \& Wulandari (2016) dalam penetapan berapa besarnya BI rate tidak hanya mempertimbangkan kondisi makro-ekonomi dalam negeri, tetapi juga mempertimbangkan pergerakan berapa besarnya tingkat suku bunga dunia (Federal Fund Rate/FFR). FFR merupakan suku bunga AS yang mengacu pada tingkat suku bunga bank dalam membayar bank lain atas pinjaman saldo cadangan yang diadakan oleh Federal Reserve (The Fed) selaku bank sentral AS. Peningkatan suku bunga oleh the fed akan mempengaruhi peningkatan suku bunga BI dan dapat mempengaruhi perekonomian, mengakibatkan turunnya harga komoditas dan mempengaruhi ekspor.

Tahun 2016-2018 total pendapatan perusahaan dan total pendapatan negara mengalami peningkatan, namun pada tahun 2018 total pendapatan perusahaan mengalami penurunan. Hal ini terjadi karena pada tahun 2018 India menaikkan tarif impor CPO dari $30 \%$ menjadi $44 \%$, dan terdapat isu bahwa Eropa tidak ingin menghitung $\mathrm{CPO}$ sebagai biofuel yang mengakibatkan harga CPO turun berkisar $-15,34 \%$ dikutip dari CNBC Indonesia. Menurut Purba, Sinaga, Novianti, \& Kustiari (2018) minyak sawit memiliki peran penting dalam perdagangan biodesel dunia, tetapi hal ini ditanggapi negatif oleh negara 
eksportir minyak nonsawit terutama oleh negara-negara Di Uni Eropa. Eropa mengendalikan impor minyak sawit dengan cara memberlakukan kebijakan tarif impor yang tinggi, bea masuk anti-dumping, kampanye negatif (isu deforestasi lahan gambut, pembakaran hutan dan HAM) dan penolakan produk minyak sawit (palm oil free pada produk makanan) hingga membuat wacana akan melarang impor biodiesel yang berbahan baku minyak sawit dari Indonesia pada tahun 2021 dan ditunda menjadi tahun 2030.

diketahui nilai signifikan dari variabel pendapatan perusahaan sebesar 0,015 yaitu lebih kecil dari 0,05 yang berarti H1 diterima, variabel pendapatan perusahaan memiliki pengaruh yang signifikan. Pertumbuhan ekonomi dapat dijadikan sebagai indikator dari proses kenaikan kapasitas produksi pada perekonomian yang terwujud yaitu kenaikan pendapatan negara. Pertumbuhan ekonomi dapat menjadi salah satu indikasi keberhasilan pembangunan ekonomi. Pertumbuhan ekonomi dapat ditandai salah satunya dengan perubahan pendapatan negara (Kholis, Astuti, \& Febrianti, 2016). Kapasitas produksi berhubungan dengan kemampuan produksi dari suatu negara, yang dapat dipengaruhi oleh produksi perusahaan dalam memenuhi permintaan pasar. Perusahaan berproduksi bertujuan untuk mendapatkan laba, sehingga produksi dari perusahaan memiliki hubungan dengan pertumbuhan ekonomi dan hasil perusahaan yang berupa pendapatan dapat berpengaruh pada pendapat negara.

\section{Pengaruh Tenaga Kerja dengan Pendapatan, Total Aset, dan Total Tingkat Upah Perusahaan}

Pembangunan ekonomi suatu negara memiliki dampak, sesuai dengan penelitian Suindyah D (2017) hasil dari pelaksanaan pembangunan ekonomi yaitu terjadinya perubahan pada bidang sektoral. Perubahan sektoral yaitu terdapat perubahan dari sektor pertanian ke sektor industri dan jasa yang digunakan. Perubahan yang terjadi ini juga membuat perubahan pada tenaga kerja, banyak tenaga kerja sektor pertanian yang pindah ke sektor industri dan jasa. Perubahan pada struktur ekonomi, yaitu dari sektor pertanian ke sektor industri dan jasa dapat menyebabkan kesempatan kerja di sektor pertanian akan mengalami penurunan. Hal ini menyebabkan diperlukannya mengetahui pengaruh variabel-variabel eksogen terhadap variabel endogen dianalisis menggunakan uji analisis jalur, disajikan pada tabel 1.

Berdasarkan Tabel 1. dapat dilihat bahwa data yang digunakan berdistribusi normal. Pengaruh antara total pendapatan perusahaan, total aset, dan total tingkat upah terhadap total tenaga kerja dapat dilihat dari nilai signifikan yang sudah dianalisis. Berdasarkan Tabel 5.3 diketahui nilai signifikan dari variabel total pendapatan perusahaan sebesar 0,154 yaitu lebih besar dari 0,05 yang berarti variabel total pendapatan perusahaan tidak memiliki pengaruh yang signifikan terhadap variabel total tenaga kerja. Analisis dengan 
menggunakan nilai signifikan 0,05 menunjukan $\mathrm{H} 2$ dari penelitian ditolak, jika menggunakan nilai signifikan 0,20 maka H2 diterima. Penelitian menunjukan bahwa pendapatan perusahaan tidak berpengaruh terhadap tenaga kerja, tetapi menurut Mankiw et al (2014) optimalisasi terhadap laba perusahaan dapat diprediksi dengan menggunakan produk marginal tenaga kerja, semakin banyak tenaga kerja yang digunakan dalam proses produksi perusahaan maka semakin banyak pula output yang dihasilkan. Produk marginal tenaga kerja (marginal product of labor, MPL) adalah jumlah dari output tambahan yang diperoleh perusahaan dari pertambahan satu unit tenaga kerja, dengan mempertahankan jumlah modal yang tetap.

Tabel 1. Hasil Analisis Jalur dan Uji Asumsi Klasik dengan Empat Variabel

\begin{tabular}{lrrrr}
\hline \multicolumn{1}{c}{ Variabel } & Beta & \multicolumn{1}{c}{ Sig. } & Sig. (2-tailed) & VIF \\
\hline Konstanta & & 0,277 & & \\
Total Pendapatan Perusahaan & 0,08 & 0,154 & 0,426 & 1,041 \\
Total Aset & 0,877 & 0 & 0,958 & 1,389 \\
Total Tingkat Upah & $-0,057$ & 0,369 & 0,101 & 1,351 \\
\hline $\mathrm{R}^{2}$ & 0,753 & & & \\
Adj R & 0,734 & & & \\
Durbin - Watson & 2,036 & & & \\
One KS & 0,240 & & & \\
\hline
\end{tabular}

Sumber : data primer, 2020

Pengaruh antara variabel total aset terhadap total tenaga kerja dapat dilihat dari nilai signifikan yang sudah dianalisis. Berdasarkan Tabel 5.3 diketahui nilai signifikan dari variabel total aset sebesar 0,000 yaitu lebih kecil dari 0,05 yang berarti variabel total aset memiliki pengaruh yang signifikan terhadap variabel total tenaga kerja, maka H3 penelitian diterima. Menurut Wufron (2017) total dari tenaga kerja tidak berarti dapat menunjukkan besar kecilnya ukuran suatu perusahaan, dari total tenaga kerja tidak selalu menjadi indikator ukuran suatu perusahaan. Perusahaan yang termasuk pada industri padat modal dengan investasi real assets mesin-mesin produksi memiliki kapitalisasi pasar yang lebih besar, jika dibandingkan dengan industri padat karya yang lebih memperbanyak tenaga kerja. Alat dan teknologi yang digunakan perusahaan termasuk salah satu aset pada perusahaan, sehingga total aset dapat mempengaruhi tenaga kerja karena tergantikannya tenaga kerja manusia digantikan oleh tenaga kerja mesin yang termasuk pada aset tidak lancar perusahaan. Aset tidak lancar memiliki jangka waktu yang panjang. Menurut Mankiw et al (2014) kemajuan teknologi tidak begitu berpengaruh terhadap jumlah pekerja aktual yang meningkat, namun sebenarnya setiap pekerja menghasilkan unit yang lebih banyak selama waktu kerja. Produksi

382 | Anas Tain, Ary Bakhtiar; Analisis Pengaruh Perkembangan... 
tenaga kerja perusahaan akan lebih optimal karena adanya kemajuan teknologi, sehingga perusahaan memiliki berbagai aset untuk pengoptimalan produksi yang berorientasi pada pendapatan perusahaan yang tinggi. Tenaga kerja memiliki peran dalam operasional teknologi sehingga total aset pada perusaan berpengaruh terhadap tenaga kerja perusahaan.

Pengaruh hubungan antara variabel total tingkat upah terhadap total tenaga kerja dapat dilihat dari nilai signifikan yang sudah dianalisis. Berdasarkan tabel diketahui nilai signifikan dari variabel total tigkat upah sebesar 0,369 yaitu lebih besar dari 0,05 yang berarti variabel total tingkat upah tidak memiliki pengaruh yang signifikan terhadap variabel total tenaga kerja, maka $\mathrm{H} 4$ penelitian ditolak. Hasil uji analisis jalur menunjukan bahwa varibel eksogen tidak memiliki pengaruh terhadap variabel endogen. Menurut Sulistiawati (2012) upah memiliki kedudukan yang strategis, yaitu untuk pekerja dan juga keluarganya, bagi perusahaan serta bagi kepentingan nasional. Upah dipergunakan untuk membiayai dan memenuhi kebutuhan hidup dirinya dan juga keluarganya serta sebagai stimulus bagi peningkatan produktivitas. Upah menjadi salah satu komponen pada biaya produksi yang dapat mengurangi laba perusahaan yang dihasilkan. Perusahaan berusaha bagaimana agar dapat menekan upah, sampai pada angka yang paling minimum sehingga laba perusahaan mengalami peningkatan, tetapi hasil analisis tidak menunjukan adanya pengaruh antara total tingkat upah dengan tenaga kerja sedangkan upah termasuk pada biaya produksi yang dapat mempengaruhi permintaan tenaga kerja suatu perusahaan. Perusahaan yang mampu dan memiliki sistem keuangan yang baik, merasa mampu untuk memberi gaji yang tinggi serta total dari tenaga kerja yang tidak berpengaruh.

\section{Pengaruh Tenaga Kerja dengan Pendapatan Negara}

Ekonomi suatu negara dilihat dari pertumbuhan ekonominya. Menurut Hellen, Mintarti, \& Fitriadi (2018) pertumbuhan ekonomi mencerminkan bagaimana aktivitas perekonomian akan menghasilkan tambahan pendapatan masyarakat pada suatu periode tertentu. Aktivitas perekonomian adalah dimana proses penggunaan faktor-faktor produksi bertujuan untuk menghasilkan output. Hasil analisis akan menunjukan apakah terdapat pengaruh atau tidak antar variabel. Output analisis jalur disajikan Tabel 2. 
Tabel 2. Hasil Analisis Jalur dan Uji Asumsi Klasik dengan Dua Variabel

\begin{tabular}{llll}
\hline \multicolumn{1}{c}{ Variabel } & Beta & Sig. & VIF \\
\hline Konstanta & & 0,000 & \\
Total Tenaga kerja & 0,874 & 0,001 & 1 \\
\hline $\mathrm{R}^{2}$ & 0,763 & & \\
Adj R & 0,734 & & \\
Durbin - Watson & 2,022 & & \\
One KS & 0,909 & & \\
\hline
\end{tabular}

Sumber : Data Primer, diolah 2020

Berdasarkan Tabel 2. dapat dilihat bahwa data berdistribusi normal. Upah memiliki kedudukan bagi pemerintah sebagai media pemerataan pendapatan dan peningkatan kesejahteraan hidup masyarakat. Upah minimum ditetapkan oleh pemerintah, kenaikan upah minimum bagi pekerja akan memperbaiki daya beli masyarakat (Pratama, 2019). Berdasarkan persamaan pendapatan negara yang diantaranya terdapat konsumsi sebagai penyumbang pendapatan negara, maka kenaikan total tingkat upah akan berpengaruh pada pola konsumsi pekerja yang juga dapat mempengaruhi pendapatan negara. Pendapatan pekerja yang meningkat akan membuat konsumsi juga meningkat karena rasa ingin memiliki yang lebih dari sebelumnya. Peningkatan pada tingkat upah dapat mempengaruhi total tenaga kerja pada perusahaan, karena upah termasuk dalam biaya produksi dimana perusahaan berupaya untuk meminimalisir biaya produksi dan mengoptimalkan produksi dengan tujuan mendapatkan laba yang tinggi. Pemerintah sebagai penentu dalam menetapkan tingkat upah harus melihat banyak faktor yang berkaitan dalam memberlakukan suatu kebijakan.

Peran pemerintah dibutuhkan saat terjadi pertambahan penduduk tiap tahunnya, sesuai dengan yang disampaikan Fitriani (2015) pemerintah memiliki peran yang sangat penting untuk mengatur kegiatan ekonomi, yaitu mengendalikan kestabilan ekonomi serta meningkatkan perekonomian setiap daerah. Teori determiasi pendapatan negara pemerintah memiiki peran dalam pengeluaran pemerintah (government ex-penditure) dan juga penerimaan (tax). Tenaga kerja dan pendapatan negara memiliki pengaruh dalam pertumbuhan ekonomi nasional. Angka pengangguran yang tinggi akan menghambat pertumbuhan ekonomi, serta pendapatan masyarakat yang rendah membuat daya konsumsi masyarakat rendah yang dapat mempengaruhi pendapatan negara. Tenaga kerja suatu perusahaan akan menerima upah yang digunakan untuk konsumsi kebutuhan, konsumsi yang dilakukan ini akan menyumbang dalam pendapatan negara.

384 | Anas Tain, Ary Bakhtiar; Analisis Pengaruh Perkembangan... 


\section{Pengaruh Pendapatan Negara dengan Tenaga Kerja}

Ukuran keberhasilan pembangunan suatu negara, terutama untuk negara Indonesia salah satunya adalah tingkat pertumbuhan ekonomi. Pembangunan ekonomi yang berfokus pada sektor industri akan menyebabkan meningkatnya peranan sektor industri pada negara, karena pengembangan sektor industri pada bidang pertanian merupakan bagian yang cukup penting dari pertumbuhan ekonomi Indonesia (Suindyah D, 2017). Pertumbuhan ekonomi suatu negara dapat dipengaruhi banyak hal dalam aktifitas ekonomi negara, salah satunya yaitu pendapatan negara dan tingkat pengangguran tenaga kerja. Penelitian dilakukan untuk mengetahui apakah terdapat pengaruh pendapatan negara dengan tenaga kerja, menggunakan analisis jalur yang sebelumnya dilakukan uji normalitas data. Hasil analisis disajikan sebagai berikut :

Tabel 3. Hasil Analisis Jalur dan Uji Asumsi Klasik dengan Dua Variabel

\begin{tabular}{llll}
\hline \multicolumn{1}{c}{ Variabel } & Beta & Sig. & VIF \\
\hline Konstanta & & 0,000 & \\
Total Pendapatan Negara & 0,874 & 0,001 & 1,000 \\
\hline $\mathrm{R}^{2}$ & 0,763 & & \\
Adj R & 0,734 & & \\
Durbin - Watson & 2,292 & & \\
One KS & 0,909 & & \\
\hline
\end{tabular}

Sumber : data primer, 2020

Berdasarkan Tabel 3. dapat dilihat bahwa data yang digunakan berdistribusi normal. Pertumbuhan penduduk menjadi salah satu masalah pokok dalam pembangunan ekonomi suatu negara. Pengaruh pertambahan penduduk ini dapat dilihat pada penyediaan kebutuhan-kebutuhan pokok secara total harus ditambah terutama penyediaan pangan dan dapat mengakibatkan naiknya angkatan kerja. Jumlah penduduk tumbuh sama cepat dengan pendapatan negara, maka menyebabkan pendapatan per kapita tidak bertambah (Sukirno, 2012). Sejalan dengan hasil analisis berdasarkan Tabel 5.4 yang menunjukan nilai sig. sebesar 0,001 lebih kecil dari 0,05 yang berarti H6 diterima, yaitu terdapat pengaruh pendapatan negara terhadap tenaga kerja. Pertumbuhan penduduk akan meningkatkan jumlah permintaan suatu barang untuk memenuhi permintaan, maka jumlah produksi akan bertambah dan meningkatkan angkatan kerja. Permintaan produk yang meningkat dapat mendorong investor untuk melakukan investasi, yang dapat meningkatkan pendapatan negara dan berpengaruh terhadap pertumbuhan ekonomi.

Hal yang sama disampaikan oleh Purba et al (2018) peranan investasi, baik dari investasi pemerintah maupun investasi daari swasta memiliki peran sangat penting dalam pembangunan ekonomi, karena kegiatan investasi tidak hanya 
dapat meningkatkan permintaan agregat tetapi juga akan meningkatkan pemasaran agregat melalui pengaruh yang dimiliki terhadap kapasitas produksi. Meningkatnya kapasitas produksi akan meningkatkan produktivitas, sehingga dalam perspektif jangka waktu yang lama investasi akan meningkatkan capital stock. Setiap penambahan capital stock akan meningkatkan kemampuan masyarakat untuk menghasilkan output (produk) yang nantinya dapat meningkatkan Produk Domestik Bruto (PDB), secara tidak langsung dapat meningkatkan kesempatan kerja karena peningkatan produktivitas membuka peluang terciptanya lapangan kerja.

Pendapatan negara salah satu sumbernya yaitu dari peran investasi dalam negara sesuai dengan penelitian Kholis, Astuti, \& Febrianti (2016) Investasi dianggap sebagai salah satu faktor yang dapat mendorong pertumbuhan ekonomi nasional. Penerapan kebijakan dari adanya hubungan timbal balik antara tingkat investasi dan tingkat pendapatan tersebut adalah pada pembuatan proyeksi kebutuhan investasi tahunan dan pencapaian pertumbuhan ekonomi dimasa yang akan datang. Asumsi yang diberlakukan bahwa hubungan timbal balik tersebut terjadi, maka dalam membuat proyeksi investasi harus memperhitungkan variabel pertumbuhan ekonomi, dan sebaliknya dalam memproyeksikan angka pertumbuhan ekonomi, variabel investasi harus dijadikan salah satu faktor penentu. Hubungan timbal balik dari investasi dengan pendapatan dapat mempengaruhi tenaga kerja karena, jika investasi terjadi maka akan membuka lapangan pekerjaan sehingga jumlah pengangguran akan berkurang dan total tenaga kerja bertambah. Tingkat pendapatan bertambah dari tingkat investasi hal ini juga membuat bertambahnya jumlah tenaga kerja.

\section{SIMPULAN DAN SARAN}

\section{Simpulan}

Berdasarkan data hasil analisis dan pembahasan penelitian dapat diambil kesimpulan. Total pendapatan perusahaan sektor pertanian berpengaruh secara signifikan terhadap pendapatan negara. Total pendapatan perusahaan tidak berpengaruh secara signifikan terhadap total tenaga kerja perusahaan sektor pertanian, total aset perusahaan berpengaruh secara signifikan terhadap total tenaga kerja perusahaan, dan total tingkat upah perusahaan tidak berpengaruh secara signifikan terhadap total tenaga kerja perusahaan. Total tenaga kerja memiliki pengaruh yang signifikan terhadap pendapatan negara dan pendapatan negara memiliki pengaruh yang signifikan terhadap total tenaga kerja. 


\section{Saran}

Perusahaan diharapkan dapat lebih mengutamakan penggunaan tenaga kerja manusia dibandingkan dengan tenaga kerja mesin. Pertambahan jumlah angka pengangguran dapat mengganggu pertumbuhan ekonomi negara. Pemerintah diharapkan mampu membuat kebijakan yang menguntungkan berbagai pihak baik perusahaan dan tenaga kerja. Hal ini berkait dalam pertumbuhan ekonomi yang melingkupi banyak aspek.

\section{DAFTAR PUSTAKA}

Fitriani, N. 2015. Pengaruh Tenaga Kerja Dan Pengeluaran Pemerintah Terhadap Pertumbuhan Ekonomi Provinsi Diy Tahun 2007-2015. Jurnal Pendidikan Dan Ekonomi, 7: 42-50.

Ghozali, I. 2013. Aplikasi Analisis Multivariate dengan Program SPSS. Semarang: BP Universitas Semarang.

Hasibuan, M. 2014. Manajemen Sumber Daya Manusia (Edisi Revisi). Jakarta: Bumi Aksara.

Hellen, H., Mintarti, S., \& Fitriadi, F. 2018. Pengaruh investasi dan tenaga kerja serta pengeluaran pemerintah terhadap pertumbuhan ekonomi serta kesempatan kerja. Inovasi, 13(1), 28.

Kholis, M., Astuti, D., \& Febrianti, R. 2016. Hubungan antara Pendapatan Nasional dan Investasi di Indonesia (Suatu Kajian Ekonomi Makro dengan Model VAR). Jurnal Organisasi Dan Manajemen, 12(1): 65-78.

Mankiw, Gregory N, Euston Quah, Peter Wilson 2014. Pengantar Ekonomi Makro. Jakarta: Salemba Empat.

Maruta, H. 2018. Analisis Break Even Point (BEP) Sebagai Dasar Perencanaan Laba Bagi Manajemen. Sekolah Tinggi Ilmu Ekonomi (STIE) Syariah Bengkalis, 20.

Nasution, A. H., \& Faisal. 2016. Analisis Faktor Faktor yang Mempengaruhi Pajak Ekspor terhadap Perdagangan Minyak Sawit di Indonesia. Pendidikan Ekonomi Dan Bisnis, 8(1): 61-72.

Pratama, R. et al. 2019. Analisis Pengaruh Investasi, Tenaga Kerja Dan Tingkat Pendidikan Terhadap Pertumbuhan Ekonomi Dan Dampaknya Terhadap Kemiskinan Di Propinsi Sulawesi Utara. Jurnal Pembangunan Ekonomi Dan Keuangan Daerah, 19(4): 1-17.

Purba, H. J., Sinaga, B. M., Novianti, T., \& Kustiari, R. 2018. The Impact of Trade Policy on Indonesia' s Biodiesel Industry Development. Jurnal Agro Ekonomi, 36(1): 1-24.

Retnasih, N. R., Agustin, G., \& Wulandari, D. 2016. Analisis Guncangan Eksternal Terhadap Indikator Moneter dan Makro Ekonomi Indonesia. Jurnal Ekonomi Dan Ekonomi Studi Pembangunan, 8(2): 101-113. 
Suindyah D, S. 2017. Pengaruh Investasi, Tenaga Kerja Dan Pengeluaran Pemerintah Terhadap Pertumbuhan Ekonomi Di Propinsi Jawa Timur. EKUITAS (Jurnal Ekonomi Dan Keuangan), 15(4): 477.

Sukirno, S. 2012. Makroekonomi Modern. Jakarta: Raja Grafindo Persada.

Sulistiawati, R. 2012. Pengaruh Upah Minimum terhadap Penyerapan Tenaga Kerja dan Kesejahteraan Masyarakat di Provinsi di Indonesia. Pontianak.

Wufron. 2017. Pengaruh Ukuran Perusahaan Terhadap Kinerja Keuangan Serta Implikasinya Terhadap Nilai Perusahaan Pada Perusahaan Manufaktur yang Terdaftar di Bursa Efek Indonesia. Jurnal Wacana Ekonomi, 16(3): 022-033. 